\title{
Feedback Used in Classrooms with Native English and Non-Native English Teachers
}

\author{
Sen Zhang (Corresponding Author) \\ M.A. student, Department of Languages and Linguistics, Faculty of Liberal Arts \\ Prince of Songkla University, Hat Yai Campus, Songkhla, Thailand \\ E-mail: mutation_mo@hotmail.com \\ Monta Chatupote \\ Assoc. Prof. Dr., Department of Languages and Linguistics, Faculty of Liberal Arts \\ Prince of Songkla University, Hat Yai Campus, Songkhla, Thailand \\ E-mail: monta.ch@psu.ac.th
}

Received: March 6, 2014 Accepted: March 23, 2014 Published: March 23, 2014

doi:10.5296/ijele.v2i1.5347 URL: http://dx.doi.org/10.5296/ijele.v2i1.5347

\begin{abstract}
Based on Lyster and Ranta (1997), this current study made a comparison between native and non-native English speaking teachers' corrective feedback to students' errors, and also between different teachers' feedback types and students' uptake. The database consisted of 738 minutes' or 12.3 hours' classroom observation, including two types of teachers, six types of corrective feedback and two types of student uptake. Results showed that recast was the most frequently used feedback type across all the teachers, which simultaneously led to low rate of learner repairs; non-native English speaking teachers provided overwhelmingly more feedback than native teachers, and they tended to use more recast; both native and non-native teachers preferred to use varied kind of feedback at similar distribution which might suggest that corrective feedback did not necessarily rely on teacher types with students of the same proficiency level; elicitation tended to be the most effective feedback type in both native and non-native teachers' class, which might indicate that feedback types which can trigger negotiation of form were effective no matter what types of teachers use them. The results suggested that teachers should avoid using recast and opt for elicitation for more effective learning.
\end{abstract}

Keywords: Native and Non-native English Teachers, Corrective Feedback, Feedback Effectiveness 


\section{Introduction}

Corrective feedback, which plays a scaffolding role in classroom interaction process, has been the focus and prominence of many SLA researchers for the past few decades (Chaudron, 1977, 1986, \& 1988; Doughty, 1994a; Long, 1996; Lyster \& Ranta, 1997; Panova \& Lyster, 2002; Suzuki, 2004; Li, 2010). Numerous studies, investigating feedback features and effectiveness, derived from Interaction Hypothesis (Long, 1996) which stated that implicit negative feedback, triggering interactional modification, could facilitate learners' comprehension, and Output Hypothesis (Swain, 1985), which asserted that corrective feedback, eliciting modified output, could complete the whole language mastery process. Gass and Varonis (1994) concluded that learners would be able to make some reformulations to the detected language discrepancies if the teachers can provide negotiable input. Gass (1997), Schmidt and Frota (1986) suggested that corrective feedback provided by teachers offers an opportunity for students to perceive the mismatches between their language production and the target discourse forms, potentially to reformulate their language outcomes.

Based on these theories, previous researches explored the relationships between learner error and teacher feedback, corrective feedback and learner uptake, corrective feedback and learner repair, teacher feedback and classroom context types (Lyster \& Ranta, 1997; Panova \& Lyster, 2002; Sheen, 2004; Suzuki, 2004). Flourishing and prosperous findings were presented during different phases. For example, recast was testified as the most frequently used corrective feedback by different studies (Lyster \& Ranta, 1997; Ellis et al, 2001; Panova \& Lyster, 2002; Suzuki, 2004); teachers tended to use varied types of teaching strategies (Lyster \& Ranta, 1997); there were both similarities and differences between feedback types observed in different studying contexts (Heift, 2004; Sheen, 2004; Suzuki, 2004; Li, 2010); teachers would better take learners' proficiency level into consideration when providing feedback (Lyster \& Ranta, 1997; Sara, 2010; Parviz, 2012).

However, review of early studies, few set foot in the effects of one variable - teacher types, on corrective feedback, learner error and uptake. Thus, this present study focused on comparing the relationship between types of teacher (native and non-native English teachers) and corrective feedback, exploring the teacher type effects on learner error and uptake, attempting to find the effective feedback used by different types of teacher, and finally providing some practical instructions for future teaching and researching.

\section{Literature Review}

\subsection{Observational Classroom Studies}

In this part, review of previous studies presented how observational classroom researches examined corrective feedback and learner uptake in different contexts or with varied target groups, and how they defined and demonstrated the successful feedback types. Some common features about corrective feedback and learner uptake were summarized based on those studies. Corrective feedback refers to teachers' responses, comments or reactions to learners' inappropriate utterances, which may include correct forms to elicit learners to make 
some reformulations of their mistakes. Learner uptake, as Lyster and Ranta (1997) defined, was learners' discourse following instantly the lecturer's correction strategies which forms the response to teacher's intention of reminding the student of the inappropriate address. Yoshida (2010) added that learner uptake showed the student's understanding of teacher's comments or suggestions.

In 1997, based on Chaudron's (1977, 1986, \& 1988) intricate model of error correction process and Doughty's (1994a) coding of learner error and teacher feedback, Lyster and Ranta (1997) devised an error treatment sequence which included learner error, teacher feedback and learner uptake. Using this sequence in the observation of 4 French immersion classrooms, Lyster and Ranta (1997) studied the frequency and distribution of each feedback type and learner uptake following each type of feedback. Results demonstrated that recast was the most frequently used feedback type among all the four teachers, while leading to the least learner repair; feedback types which initiated the negotiation or interaction between teacher and students (elicitation, clarification request, repetition and metalinguistic feedback) tended to be more successful in eliciting learner-generated repair; teachers might better take learner's proficiency level into consideration when providing correction to different learners.

Reviewing several observational classroom studies on feedback and uptake, Panova and Lyster (2002) made a comprehensive summary of feedback type and effectiveness, teacher and students' understanding of feedback, and factors affecting choices of feedback. Motivated by Lyster and Ranta (1997), Panova and Lyster (2002) examined the error treatment sequence in an adult ESL classroom, tested and verified the applicability of Lyster and Ranta's (1997) corrective discourse model in another instructional context, and found some similar results, such as that recast was also the most often used corrective feedback in this study. Meanwhile, results indicated that learners gave few responses and made even fewer repairs in current situation, which might be supported by the hypothesis that learners would benefit more from retrieving their own knowledge and comprehension than merely hearing the correct target forms.

Inspired by Lyster and Ranta (1997), Suzuki (2004), using the same error correction sequence, conducted a study within the adult ESL students and made a comparison of the results with Lyster and Ranta's (1997) findings. Observational results showed both similarities, such as the distributions of teacher feedback followed by learners' errors which was the same to Lyster and Ranta's (1997) results, and differences, such as rate of learner uptake to some special types of feedback which was different from theirs (Lyster \& Ranta, 1997). These were explained by the different classroom contexts, students' ages and motivation, teacher experience and the target language in this study.

Based on Lyster and Ranta's (1997) clarification of teacher correction moves and student responses, Sheen (2004) compared the error treatment sequence happening in four classrooms, namely, French Immersion, Canada ESL, New Zealand ESL and Korean EFL, and found that recast was the most frequently used feedback type among all the four classrooms. Results suggested that when the teaching focus was more on form and the function of recast was prominent, recast could lead to more learner responses and repairs; meanwhile the 
distributions of corrective feedback and learner uptake didn't necessarily depend on classroom contexts.

Li (2010), conducting a meta-analysis to 33 primary studies, testified the effectiveness of corrective feedback. Through setting comprehensive variables, the results demonstrated that learners perceived implicit feedback better than explicit feedback; feedbacks given during foreign language contexts were more effective than second language context; native teachers tended to provide more effective feedback than other teachers or computers. However, there were still some factors suggested by Li (2010) that needed to be studied, such as learners' age, proficiency, classroom context and even interlocutor types.

Seldom previous studies on corrective feedback and learner uptake focused on the relationship between lecturer types and corrective feedback, or even learner uptake. Motivated by these studies, especially Lyster and Ranta (1997) and Panova and Lyster (2002), the current study aimed at exploring the effect of a new variable, teacher types (native and non-native English teachers), on their choices of corrective feedback to learner errors, and on students' response of teacher feedback. The present study also intended to find the most effective feedback type in each classroom settings or with each type of teachers, thus providing some actual instructions for both future studies and teaching experience.

\subsection{Basic Concepts}

\subsubsection{Types of Feedback}

According to different criteria and characteristics, feedback can be categorized in various ways. Some typical classifications used in various studies are presented as follows.

Doughty (1994a) conducted a pilot study about classroom interaction between teachers and students, of which, she coded teachers' turns to students' errors as type of feedback, namely, clarification request, repetition, recast, expansion, or translation. Later, based on the functions of different teacher instructions, Lyster and Ranta (1997) improved the categories of feedback and devised a new taxonomy of feedback, that was explicit correction, recasts, elicitation, metalinguistic feedback, clarification requests, and repetition, which integrally reflected teachers' instructive moves in classroom and thus was cited by many researchers as a criteria. Ohta (2001), however in a following study, added two categories into Lyster and Ranta's (1997) six types of feedback, namely, re-asks and delayed recast.

In his consecutive research, Lyster (2001) further classified and integrated those six types of feedback into three types, namely recast, explicit correction and negotiation of form. These three types of feedback were different in the extent of providing corrective forms to the incorrect utterance. Providing negotiation of form, teachers encourage the students to retrieve from their own knowledge and the context, process peer- and self-repair rather than merely rephrase the corrective answer. Meanwhile, the author distinguished recast from explicit correction due to their extent of giving correct form. Explicit correction referred to just providing accurate form, while recast showed the correction inside the context.

Gurzynski-Weiss and Révész (2012), in their classroom interaction study, used 9 types of 
feedback, which were recasts, confirmation checks, clarification requests, repetitions, negotiations, elaborations, elicitations, overt corrections and metalinguistic information. Nonetheless, Long (1996) divided them into implicit feedback, which includes recasts, confirmation checks, clarification requests, repetitions, negotiations, elaborations, and elicitations, and explicit feedback, which consists of overt corrections and metalinguistic information.

Overall, Lyster and Ranta (1997), which devised an error treatment model to discuss the relationship between teacher feedback and learner uptake, presents the way of counting and comparing feedback and uptake in different classroom environments for this current study.

\subsubsection{Learner Uptake}

Usually, when studying teacher feedback in classroom, learner uptake, as the following sequence or the indication of feedback, was also used to compare the relationship between teacher feedback and learner responses, and to make the whole error treatment sequence integrated.

When come to types of learner uptake, according to different proficiency level, students may tend to give different kinds of responses. Two types of student uptake (repair and needs repair) were used in Lyster and Ranta's (1997) study. Repair meant that students' errors were finally corrected; while needs repair referred to that students' responses followed by teacher feedback still included some mistakes. In order to clearly present students' responses and reaction of teacher feedback, four sub-types of repair (repetition, incorporation, self-repair and peer-repair) and six sub-types of needs repair (acknowledgement, same error, different error, off target, hesitation and partial repair) were also used and analyzed to complete the error treatment sequence. In Yoshida's (2010) study, learner response was coded with different clarification, namely successful uptake, unsuccessful uptake, acknowledgement, enquiry, no response and no chance.

To keep the consistency of teacher feedback and learner uptake, and to compare the relationship between feedback and uptake, Lyster and Ranta's (1997) types of learner uptake were also applied into this current study. But, due to the different classroom environment and students' characters, the current study made some adjustment of both teacher feedback and learner uptake to suit the content.

\subsubsection{Feedback Effectiveness}

Inspired especially by Lyster and Ranta (1997), the current study chose learner uptake and repair as the indication of successful teacher feedback. However, Ohta (2000) claimed that uptake was just a language phenomenon, thus may not surely lead to learners' language obtainment. Mackey and Philp (1998) added that uptake was not an effective measure to check feedback effectiveness. Even Lyster and Ranta (1997), who used repair as a method of learner understanding of teacher feedback, stated that choice of teacher feedback may have an effect on learner repair, thus learner repair cannot guarantee learner knowledge acquisition.

Later, Williams (2001), who designed a tailor-made test checking feedback impact, noted that 
language improvement took place when repair occurred. Loewen (2002), using tailor-made post-tests or delayed post-tests, argued that acquisition of vocabulary and grammar was greatly related to learners' successful uptake. Both these two studies confirmed the indicator role of learner uptake and repair, and prompted the current study to concentrate on the relationship between teacher feedback and learner acquirement. Thus, in this study, learners' self-generated repair was defined as the indication of effective teacher feedback.

\section{Research Questions}

3.1 What are the differences and similarities of feedback found in classes taught by native English speaker and non-native English speaker teachers?

3.2 What are the most effective ways of providing feedback in those different classroom environments?

\section{Methodology}

\subsection{Database}

This current study chose similar target groups to Lyster and Ranta (1997), namely four English listening and speaking classes within EFL contexts. Together, two native English-speaking teachers and two Thai English teachers were selected on their willingness of being observed. All of them taught the same course named Fundamental English listening and speaking, which based on Spada and Frohlich's (1995) believes that there were the interactions between lecturers and learners most of time in oral activities, which was just the theme and content of this course. Teacher 1 and 2 are two Thai English teachers who share some similar background: Thai female English teachers, 9 to 10 years' experience in teaching first year university students at a southern Thailand University, and teach fundamental English courses. Teacher 3 and 4 come from English-speaking countries, one from England and the other from Canada. Both of them seem to start their teaching career at this University less than one year ago. However, during the observation, Teacher 4 tended to have more teaching skills in dealing with students.

The students chosen were first year students from four different faculties in the University located at the south of Thailand. They enrolled in the Fundamental English Listening and Speaking course during the first semester of the academic year 2013 with one of the four different teachers above.

During the observation process, a camera was placed at the back of each classroom, and one researcher attended every class to assure the quality of the video and also note the interactions happening between the students and teacher in the classroom. The reasons of conducting a video survey are that video recording can offer the overall perspective of teaching-learning procedures in classroom, making the data more precise, and also provide an overview of actual learner acquisition process, especially teachers' perception of students' errors and the whole error treatment sequence in class. Totally 738 minutes' or 12.3 hours' classroom observation formed the database for the present study. 


\subsection{Data Analysis}

\subsubsection{Error}

Based on Lyster and Ranta (1997) and concentrating on the current situation and focus, this present study coded student utterances which had the potential of containing errors, except short utterances like simple acknowledgement, as student turns. Student turns, which included as least one mistake, are defined as student error. According to the different definitions, errors in this study are classified as lexical error, grammatical error, phonological error, content error and students' unconscious use of L1.

\subsubsection{Types of Feedback}

Teacher feedback is coded into six types based on their definitions, namely recast, clarification request, metalinguistic feedback, elicitation, explicit correction and repetition.

1. Recast refers to teachers' partial or complete reformulation of students' error utterance without pointing out what the mistake is.

(1) Ss: karaoke (phonological error)

T: Ok, /,kærı'ouki/. (recast-PE)

Ss: /,kærı'orki/ (repeat-repair-Rec-PE)

Translation in this study is also coded in recast, through which teachers translate students' L1 into English, or elicit students to speak out the L1 by showing them the English address.

(2) Ss: Thai word. (L1 error)

T: To sleep for a short while. Right, yeah! Sleep for a short period of time. (translation-recast-L1-no uptake)

(3) T: So a play in Thai is called ...? (translation-recast-L1-no uptake)

Ss: Thai word (L1)

2. Explicit Correction means that teachers tell the students where their error is and provide the correct form.

(4) Ss: he said My sister ... (grammatical error)

T: He said "My" No, not my, "his sister" (explicit correction-GE)

Ss: his sister (repeat-repair-EC-GE)

3. Clarification Request refers to that teachers usually make a confirmation or recheck the students' utterance which may include at least one error to give students opportunity to look back. Or sometimes, they may provide 2 choices for the students to choose by themselves.

(5) Sb: sea (lexical error)

T: You said the sea or the beach? (clarification-LE) 
Sb: The beach. (self-repair-C-LE)

4. Elicitation is the strategy that teachers encourage or elicit students to find out the alternative correct form retrieving from their own knowledge forwardly by using methods of pausing or asking some opening questions.

(6) Se: I dinner in a restaurant. (grammatical error)

T: I ... ? Verb, verb!! I ... (elicitation-GE)

Se: I have dinner ... (de-NR-GE-E)

T: I have ??? I h...? (elicitation-GE)

Ss: I had ... $\quad$ (self-repair-E-GE)

5. Metalinguistic Feedback is the way teacher give some comments or questions to the correctness of students' utterances.

(7) Sb: Oh, I had a great time.(phonological error)

T: Really, ok, stop.(point to Girls)“'O, I had a great time” (T speaks just same to the boys, without intonation.) Was that really great? (metalinguistic-PE)

Ss: no (acknowledgement-needs-repair)

6. Repetition means that teachers repeat students' wrong utterance with rising intonation.

(8) S: watching a music (lexical error)

T: watching .. (repetition-LE)

S: watching a movie (self-repair-R-LE)

\subsubsection{Types of Uptake}

Referring to Lyster and Ranta's (1997) study, there are mainly 2 types of learner uptake, repair and needs-repair. Repair means that after teachers' error treatment, students tend to reformulate their error utterance with correct form. While, needs-repair refers to that students' reformulated utterance still include some incorrect or inappropriate parts.

Repair

Repair includes 4 sub types, namely incorporation, repetition, self-repair and peer-repair. Repetition means that students simply repeat teachers' correct utterance. While, incorporation means that students use or repeat teachers' correct form and create long utterance. Self-repair means that students correct their own errors followed by teachers' feedback without providing the correct form. And peer-repair means that the other students help the one who made error correct the mistake followed by teachers' feedback without providing the correct form.

(9) Ss: don't (grammatical error) 
T: No, I don't or no, I didn't? (clarification-GE)

Ss: I didn't. (self-repair-C-GE)

Needs-repair

Needs-repair in this study includes acknowledgement, hesitation, same error, different error, off target and partial repair.

(10) Ss: They went to a karaoke club. (Thai accent - phonological error)

T: (put hand on the ear to hear) A what? (clarification-PE)

Ss: Kala ok. (same error-needs-repair-PE-C)

T: Ka la ok??? Really?? (clarification-PE)

Ss: Yeah. (same error-needs-repair-PE-C)

T: So kala ok is Thai (Ss together) accent, yes? Ok! How to pronounce it, can u guess? (elicitation-PE)

Ss: kala ... (same error-needs-repair-PE-E)

T: Ok, /kariouk/. (recast-PE)

Ss: /kairioke/ (repeat-repair-Rec-PE)

\section{Results}

Some facts need to be stated again that only those that had the potential of containing ill-formed address were coded as student turns; student errors were no salient in this current study, but were still believed an important factor that influence teachers' choice of feedback. The following results will focus on answering the two research questions set before respectively.

\subsection{Feedback types in classrooms with native English speaker and non-native English speaker teachers}

Teacher preferences of different types of feedback (recast, clarification, elicitation, explicit correction, repetition and metalinguistic feedback), as well as frequency of each feedback used by each of the four teachers, are presented in Table 1. Total results showed some similarities with Lyster \& Ranta's (1997) study, which may testify the reliability and applicability of the error treatment sequence in the current situation. Among all the four teachers, recast was the most frequently used feedback type of all the teachers' turns containing corrective feedback, accounting for almost half of all feedback. Clarification and elicitation were the second most frequently used categories across four teachers, both about $19 \%$ of total. The least frequently used feedback types were explicit correction, repetition, metalinguistic feedback, which exhibited a decreasing trend, $7.5 \%, 4 \%$ and $1.5 \%$ respectively. Metalinguistic feedback, which accounted for a large proportion in previous studies, in this study seemed to have little influence on the results. This may due to the fact that teachers in 
this current situation seemed to elicit responses from the students a lot and only give few comments; some changes to the definition of metalinguistic feedback was made to suit the current study which may also lead to the least frequency of using this feedback type; metalinguistic feedback co-existed with other types of feedback.

Table 1. Types of feedback used by all the teachers.

\begin{tabular}{|c|c|c|c|c|c|}
\hline & \multicolumn{4}{|c|}{ Teachers } & \multirow[t]{2}{*}{ Total } \\
\hline & 1 & 2 & 3 & 4 & \\
\hline Recast & 30 & 120 & 12 & 33 & 195 \\
\hline$\%$ within $\mathrm{T}_{-} \mathrm{TYPE}$ & $25.4 \%$ & $70.6 \%$ & $32.4 \%$ & $44.6 \%$ & $48.9 \%$ \\
\hline Clarification & 33 & 21 & 6 & 17 & 77 \\
\hline$\%$ within T_TYPE & $28.0 \%$ & $12.4 \%$ & $16.2 \%$ & $23.0 \%$ & $19.3 \%$ \\
\hline Elicitation & 34 & 18 & 11 & 12 & 75 \\
\hline$\%$ within $\mathrm{T}_{-} \mathrm{TYPE}$ & $28.8 \%$ & $10.6 \%$ & $29.7 \%$ & $16.2 \%$ & $18.8 \%$ \\
\hline Explicit Correction Count & 9 & 10 & 6 & 5 & 30 \\
\hline$\%$ within T_TYPE & $7.6 \%$ & $5.9 \%$ & $16.2 \%$ & $6.8 \%$ & $7.5 \%$ \\
\hline Repetition & 9 & 1 & 0 & 6 & 16 \\
\hline$\%$ within $T_{-}$TYPE & $7.6 \%$ & $0.6 \%$ & $0 \%$ & $8.1 \%$ & $4.0 \%$ \\
\hline Metalinguistic & 3 & 0 & 2 & 1 & 6 \\
\hline$\%$ within $T_{-}$TYPE & $2.5 \%$ & $0 \%$ & $5.4 \%$ & $1.4 \%$ & $1.5 \%$ \\
\hline Count & 118 & 170 & 37 & 74 & 399 \\
\hline$\%$ within $T_{-}$TYPE & $100.0 \%$ & $100.0 \%$ & $100.0 \%$ & $100.0 \%$ & $100.0 \%$ \\
\hline Pearson Chi-Square $\left(\mathrm{x}^{2}\right)$ & 81.50 & & Sig (2-sided) & $0.01 * *$ & \\
\hline
\end{tabular}

Overall, there are huge differences between four teachers and six types of feedback, as the Pearson Chi-Square results show in 0.01 at the significance level of 0.05 . Teacher 2 was the one who used recast the most, $70.6 \%$ of total feedback, which left no chance of providing other types of feedback. This may be as a result of too many frequently L1 used in her classroom. Even teacher 2 used a lot of L1 to communicate with the students. Thus, recast accounts for the higher proportion of her feedback. Another clear difference is the explicit correction used by teacher 3 , which accounts for $16.2 \%$ of his total feedback. This may be in virtue of his teaching style, namely teacher-centered approach, through which he explained 
more on instructions or gave more guidance for the students to follow, or that the students' passive participation 'forcing' teacher 3 to provide correct form to students' mistakes. The remaining types of feedback, clarification, elicitation, repetition and metalinguistic feedback, which constituted the negotiation of form in Lyster's (2001) study, seem well-distributed among all the four teachers. This scattering may suggest that both native and non-native teachers prefer to use the feedback which might elicit student-teacher negotiations, seemingly at the similar proportion of all their feedback types.

The comparison of each type of teachers showed that some differences existed between two Thai teachers and between two native English teachers. As can be seen in Table 1, teacher 1's use of each type of corrective feedback seemed to be well-distributed, while teacher 2 seemed to prefer recast, which accounted for more than 70 percent of her correction strategies and also left few opportunities of other feedback types. The differences between these two Thai English teachers may be owing to their diverse teaching strategies and students' various proficiency levels. For example, based on the classroom observation record and interview on teachers, possible explanation for the differences between the two Thai teachers is that due to the students' relatively lower English ability, teacher 2 preferred to communicate with students using L1, which triggered more translation (recast); on the other hand, teacher 1 vouched for her students' English level and taught in English, which allowed her to provide each feedback type well-proportionally. As for two native English teachers, teacher 3 and 4 were different in their total utility of corrective feedback, such as that feedback used by teacher 4 was double the amount of teacher 3's. This may be due to the fact that teacher 3's class was more teacher-centered, which allowed fewer chances for students to speak out; students' characters in his class tended to be constrained, thus they were not as active as those in teacher 4's class; teacher 4 seemed to be good at eliciting responses from students and would like to give comments to students' mistakes. This result may suggest that even for the same group of teachers, there are some differences existing such as their teaching strategies and own characteristics and hence, different types of feedback and level of effectiveness.

A more detailed table (Table 2) concerning native and non-native teachers and their applications of each type of feedback is shown as below. As for each type of teachers, Non-Native English teachers provided many feedbacks, totaling 288, especially the recast, which accounted for $52.1 \%$. The remaining feedback types spread in a descending order as follows: clarification (18.8\%), elicitation $(18.1 \%)$, explicit correction $(6.6 \%)$, repetition $(3.5 \%)$ and metalinguistic feedback (1\%). Of the 111 feedbacks provided by Native teachers, recast accounted for $40.5 \%$, both clarification and elicitation accounted for $20.7 \%$, explicit correction $9.9 \%$, repetition $5.4 \%$ and metalinguistic feedback $2.7 \%$. The reasons why non-native teachers provided overwhelmingly more feedback are probably that both of the two Thai English teachers preferred eliciting and their teaching pace were really fast. On the basis of large amount of students' utterances, they could possibly provide more feedback.

However, the comparison between types of teacher and their use of each type of feedback showed that there is no big difference as the result shows 0.303 at the significance level of 0.05, which may indicate that the distributions of each feedback pattern used by both native and non-native teachers are similar. No matter native or non-native English teachers, they all 
tend to use all types of feedback to tackle students' language difficulties. While if looking at each type of feedback, recast used by non-native teachers $(52.1 \%)$ is higher that native teachers $(40.5 \%)$. This may due to Thai teachers' background advantages that they could communicate with students with L1 and using recast to reformulate students' unsolicited use of L1. Meanwhile, it may be owing to that the current study redefined recast, especially translation, which included teachers' elicitation of students' knowledge from English to Thai.

Table 2. Feedback types used by Native teachers and Non-native teachers

\begin{tabular}{|c|c|c|c|c|}
\hline & & Non-native & Native & Total \\
\hline \multirow[t]{2}{*}{ Recast } & Count & 150 & 45 & 195 \\
\hline & $\%$ within T_TYPE & $52.1 \%$ & $40.5 \%$ & $48.9 \%$ \\
\hline \multirow[t]{2}{*}{ Clarification } & Count & 54 & 23 & 77 \\
\hline & $\%$ within T_TYPE & $18.8 \%$ & $20.7 \%$ & $19.3 \%$ \\
\hline \multirow[t]{2}{*}{ Elicitation } & Count & 52 & 23 & 75 \\
\hline & $\%$ within T_TYPE & $18.1 \%$ & $20.7 \%$ & $18.8 \%$ \\
\hline \multirow[t]{2}{*}{ Explicit Correction } & Count & 19 & 11 & 30 \\
\hline & $\%$ within T_TYPE & $6.6 \%$ & $9.9 \%$ & $7.5 \%$ \\
\hline \multirow[t]{2}{*}{ Repetition } & Count & 10 & 6 & 16 \\
\hline & \% within T_TYPE & $3.5 \%$ & $5.4 \%$ & $4.0 \%$ \\
\hline \multirow[t]{2}{*}{ Metalinguistic } & Count & 3 & 3 & 6 \\
\hline & $\%$ within $\mathrm{T}_{-} \mathrm{TYPE}$ & $1.0 \%$ & $2.7 \%$ & $1.5 \%$ \\
\hline \multirow[t]{2}{*}{ Total } & Count & 288 & 111 & 399 \\
\hline & $\%$ within T_TYPE & $100.0 \%$ & $100.0 \%$ & $100.0 \%$ \\
\hline \multicolumn{2}{|c|}{ Pearson Chi-Square $\left(x^{2}\right)$} & 6.03 & Sig (2-sided) & 0.303 \\
\hline
\end{tabular}

\subsection{Effective feedback in Different Classroom Environment}

In this current study, students' self-repair is the indication of successful feedback. Thus, feedback, which can lead to higher students' self-repair, is defined as effective feedback. Students' uptakes, namely repair, needs repair and no uptake, were introduced to demonstrate the effectiveness of feedback. Overall results showed some similarities to Lyster \& Ranta's (1997) study. Since Lyster \& Ranta (1997) had already testified that repairs generated by recast and explicit correction were not students-initiated, and repairs after clarification, elicitation, repetition and metalinguistic feedback were all students generated, which were 
also proved correct by this current research, this study focused more on the repairs followed by feedback which triggers negotiation of form. Results show that elicitation is the most effective feedback, of which 59\% finally leads to students' self-repair. The next two effective feedbacks are clarification and repetition, $42 \%$ and $38 \%$ respectively. Only few metalinguistic feedbacks occurred in this study, which also led to least students' repair (17\%).

Table 3. Students' responses to Non-Native and Native teachers' feedback

\begin{tabular}{|c|c|c|c|c|c|c|c|c|}
\hline \multirow{2}{*}{$\begin{array}{c}\text { Type of } \\
\text { Feedback }\end{array}$} & \multicolumn{3}{|c|}{ Non-Native } & \multicolumn{3}{c|}{ Native } & \multicolumn{2}{c|}{$\begin{array}{c}\text { Pearson } \\
\text { Chi-Square }\end{array}$} \\
\cline { 2 - 10 } & Repair & $\begin{array}{c}\text { Needs } \\
\text { Repair }\end{array}$ & $\begin{array}{c}\text { No } \\
\text { Uptake }\end{array}$ & Repair & $\begin{array}{c}\text { Needs } \\
\text { Repair }\end{array}$ & $\begin{array}{c}\text { No } \\
\text { Uptake }\end{array}$ & $x^{2}$ & $\begin{array}{c}\text { Sig } \\
(2 \text {-sided) }\end{array}$ \\
\hline Recast & 28 & 15 & 107 & 14 & 4 & 27 & 3.18 & 0.204 \\
\hline Clarification & 21 & 31 & 2 & 11 & 12 & 0 & 1.24 & 0.538 \\
\hline Elicitation & 30 & 22 & 0 & 14 & 9 & 0 & 0.07 & 0.797 \\
\hline $\begin{array}{c}\text { Explicit } \\
\text { Correction }\end{array}$ & 10 & 0 & 9 & 2 & 0 & 9 & 3.45 & 0.063 \\
\hline Repetition & 4 & 6 & 0 & 2 & 4 & 0 & 0.07 & 0.790 \\
\hline $\begin{array}{c}\text { Metalinguistic } \\
\text { Feedback }\end{array}$ & 0 & 2 & 1 & 1 & 2 & 0 & 2.00 & 0.368 \\
\hline Total & 93 & 76 & 119 & 44 & 31 & 36 & 2.96 & 0.228 \\
\hline
\end{tabular}

When further investigating the effective feedback used by different teachers, results show that elicitation is the most successful correction type for both native and non-native teachers. However, elicitation is the most successful feedback type for three teachers, except for teacher 2, whose clarification tends to be the most effective feedback type. Since this study focuses on native English speaking and non-native English speaking teachers, a more detailed table including types of teacher, feedback and learner uptake is shown in Table 3. However, as can be seen in the table, there is no significant difference between native and non-native teachers' use of every type of feedback or total provision of feedback at the significance level of 0.05 , which may indicate that the uptake distributions to each type of feedback do not rely on types of teachers in this study.

\section{Discussion and Conclusion}

Numerous studies in the past few decades focused on investigating the relationship between learner error and corrective feedback, and between corrective feedback and learner uptake. However, after reviewing of previous research results, it was found that one more variable, lecturer types, needed to be studied to seek the effect of teacher types on corrective feedback. Taking teacher types into consideration, this current study conducted a detailed research on 
teacher types and corrective feedback, including the relationship between two types of teachers and their use of feedback, and the feedback effectiveness.

As for types of feedback provided by different types of teachers, recast was found the most frequently used feedback type across all the teachers, but it simultaneously led to low rate of student repairs, which was coherent with previous studies (Lyster \& Ranta, 1997; Panova \& Lyster, 2002; Suzuki, 2004). However, there was no big difference when comparing types of teacher and types of feedback, except that non-native English teachers tended to provide overwhelmingly more feedback, especially more recast than native English teachers. This might be because non-native teachers would sometimes interact with students using L1 which may possible lead to translation, while native teachers tended to use all types of feedback equally. Clark and Paran (2007) state that non-native English speaking teachers share similar cultural background and language understanding, so it may be more convenient for them to interact with students using L1. Also, according to Noemi's (2009) finding that non-native teachers rely on eliciting students, two Thai English teachers in this study indeed preferred to encourage the students to speak a lot, which led to more student utterances. When looking into details, some differences existed when comparing two non-native teachers and those two native English teachers. Teacher 2 provided more recast while teacher 1 use varied corrective strategies at well-distributed proportion, which may be owing to their diverse teaching strategies and students' various proficiency level (Sara, 2010; Parviz, 2012). Another difference was that feedback used by teacher 4 was double the amount of teacher 3 's. This may be due to the fact that teacher 3's class was more teacher-centered, in which the teacher elaborated details to students and allowed less chance for students to speak out (Noemi, 2009). These findings might indicate that teachers, no matter native or non-native, should select alternative feedback strategies instead of using recast to make the error correction process more effective.

Meanwhile, the similarities among types of teacher and feedback may suggest that corrective feedback did not necessarily rely on teacher types in the current situation. Thus, whether native or non-native teacher, they seemed to share some similar understanding of students' mistakes, correction strategies, and expectations of students' reactions. At the same time, since all four groups of students in this current study were first year Thai university students, they may still have the same background knowledge reservations from high school, which may make them produce same errors or ill utterances. This could also affect teachers' choice of feedback. Their similar understanding of teacher corrections may also be the reason why there was no big difference between the repairs generated by students in both native and non-native English teachers' classes. Saerideh (2011) studied EFL teachers' corrective feedback moves to the learners with three levels of proficiency and concluded that learner proficiency level indeed affected teachers' choice of corrective strategies. Sara (2010) investigated the relationship between two groups of students with different proficiency levels and teachers' choice of feedback. Result demonstrated that different ability students tended to make diverse types of errors which lead to different types of teacher feedback. Lyster and Ranta (1997) were the first ones who suggested that teachers should take learners' proficiency level into consideration when giving feedback. In their study on corrective feedback, except 
for one group of students which seemed to have higher proficiency level in their study, all the other three groups had similar abilities, which could prove why the research results in these three classrooms were the same. This was also true with the current study. Overall, the students in current study who seemed to share similar proficiency level and background knowledge could possibly explain why corrective feedback in this study did not necessarily rely on teacher types. Thus, future studies or teachings which may be related to the classroom interaction should take students' proficiency level into consideration.

With regard to effective feedback, student self-generated repairs represented the effectiveness of each types of feedback in this study. Elicitation was found the most successful corrective strategy among all the teachers, except for teacher 2, whose clarification was more effective. But, in terms of native and non-native teachers, elicitation was still proved the most efficient strategy. As Lyster and Ranta (1997) stated that feedback, which could elicit negotiation of form, may encourage students to correct their mistakes by themselves using their own knowledge. De Bot (1996) also argues that students would have strong impressions on the mistakes if they could be encouraged or forced to find the discrepancies and fix them by retrieving from their own knowledge. All these may implicate that teachers would better provide the type of feedback which can generate the interaction or communication between teacher and students on students' inappropriate utterances. Moreover, no significant difference was found between native and non-native teachers' use of every type of feedback or total provision of feedback, which may indicate that the uptake distributions to each type of feedback did not rely on types of teachers in this study. This might also due to the same proficiency level of all the participants which may trigger similar errors, teacher feedback and learner uptake (Saerideh, 2011; Sara, 2010; Parviz, 2012).

All in all, this research made an audacious attempt to study the relationship between teacher types (native and non-native English teachers) and corrective feedback, teacher types and learner uptake, and teacher feedback and learner uptake, which produced abundant findings that might be applied into future studies or even teaching process. Results indicated that recast was the most frequently used feedback types in this study, especially for non-native English teachers; however, when coming to the effective feedback, elicitation was the most successful feedback that led to high rate of students' repair. Thus, in the practical situation, teachers may be better to use strategies that can trigger the negotiation or interaction between teachers and students, which could consequently lead to high rate of students-generated repairs to their mistakes, and also take students' proficiency levels into consideration whenever to provide comments or to conduct some experiences. However, since this current study was conducted only in a small scope at a University in Thailand, the time and techniques were also limited, future studies could focus on more variables, such as the effect of students' background knowledge on teachers' choice of feedback, learner proficiency with teacher feedback and teacher types to a large extent.

\section{Acknowledgement}

I would like to acknowledge gratefully professor Monta for her kind advices, instructions, encouragements and help in both my study and life in Thailand, thank greatly professor 
Chonlada and Jomjai for their patient comments, suggestions, reformulations and instructions, thanks for all the four teachers and their students who participated actively and earnestly in this research. Meanwhile, thanks a lot for the fundamental support to my research from Prince of Songkla University in Thailand. Thanks!

\section{References}

Chaudron, C. (1977). A descriptive model of discourse in the corrective treatment of learners' errors. Language Learning, 27, 29-46.

Chaudron, C. (1986). Teachers' priorities in correcting learners' errors in French immersion classes. In R. Day (Ed.), Talking to learn (pp. 64-84). Rowley, MA: Newbury House.

Chaudron, C. (1988). Second language classrooms. New York: Cambridge University Press. http://dx.doi.org/10.1017/CBO9781139524469

Clark, E., \& Paran, A. (2007). The employability of non-native-speaker teachers of EFL: A UK survey. System, 35(4), 407-430. http://dx.doi.org/10.1016/j.system.2007.05.002

De Bot, K. (1996). The psycholinguistics of the output hypothesis. Language Learning, 46, 529-555. http://dx.doi.org/10.1111/j.1467-1770.1996.tb01246.x

Doughty, C. (1994a). Finetuning of feedback by competent speakers to language learners. In J. Alatis (Ed.), GURT 1993 (pp. 96-108). Washington, DC: Georgetown University Press.

Ellis, R., Basturkmen, H., \& Loewen, S. (2001). Learner uptake in communicative ESL lessons. Language Learning, 51, 281-318. http://dx.doi.org/10.1111/1467-9922.00156

Gass, S. (1997). Input, interaction, and the second language learner. Mahwah, NJ: Erlbaum.

Gass, S., \& Varonis, E. (1994). Input, interaction, and second language production. Studies in Second Language Acquisition, 16, 283-302. http://dx.doi.org/10.1017/S0272263100013097

Gurzynski-Weiss, L., \& Révész, A. (2012), Tasks, Teacher Feedback, and Learner Modified Output in Naturally Occurring Classroom Interaction. Language Learning, 62, 851-879. http://dx.doi.org/10.1111/j.1467-9922.2012.00716.x

Heift, T. (2004). Corrective feedback and learner uptake in CALL. Cambridge University Press. ReCALL, 16(2), 416-431. http://dx.doi.org/10.1017/S0958344004001120

Li, S. (2010). The Effectiveness of Corrective Feedback in SLA: A Meta-Analysis. Language Learning, 60, 309-365. http://dx.doi.org/10.1111/j.1467-9922.2010.00561.x

Loewen, S. (2002). The occurrence and effectiveness of incidental focus on form in meaning-focused ESL lessons. Unpublished Doctoral Thesis, The University of Auckland, Auckland, New Zealand.

Long, M. H. (1996). "The role of the linguistic environment in second language acquisition". In Ritchie, William; Bhatia, Tej. Handbook of second language acquisition. San Diego: Academic Press. 413-468. http://dx.doi.org/10.1016/B978-012589042-7/50015-3 
Lyster, R., and Ranta, L. (1997). Corrective feedback and learner uptake. Studies in Second Language Acquisition, 19, 37-66. http://dx.doi.org/10.1017/S0272263197001034

Lyster, R. (2001). Negotiation of form, recasts, and explicit correction in relation to error types and learner repair in immersion classrooms. Language Learning, 51, 265-301. http://dx.doi.org/10.1111/j.1467-1770.2001.tb00019.x

Mackey, A., \& Philp, J. (1998). Conversational interaction and second language development: recasts, responses, and red herrings? Modern Language Journal, 82, 338-356. http://dx.doi.org/10.1111/j.1540-4781.1998.tb01211.x

Noemi, R. D. (2009). A Comparative study of native and non-native teachers' scaffolding techniques in SLA at an early age. Estudios Ingleses de la Universidad Complutense, vol. 17, 57-73.

Ohta, A. S. (2000). Rethinking recasts: a learner-centered examination of corrective feedback in the Japanese language classroom. In Hall, J.K. and Verplaeste, L., editors, The construction of second and foreign language learning through classroom interaction, Mahwah, NJ: Erlbaum, 47-71.

Ohta, A. S. (2001). Second language acquisition process in the classroom: Learning Japanese. Mahwah, NJ: Erlbaum.

Panova, I., \& Lyster, R. (2002). Patterns of Corrective Feedback and Uptake in an Adult ESL Classroom. Tesol Quarterly, 36 (4), 573-595. http://dx.doi.org/10.2307/3588241

Parviz, A. E. (2012). English Language Teachers' Corrective Feedback Types in relation to the Learners' Proficiency Levels and Their Error Types. Journal of Academic and Applied Studies, Vol. 2(8) \& 2(9), 37-51.

Philp, J. (2003). Constraints on "noticing the gap": non-native speakers' noticing of recasts in NS-NNS interaction. Studies in Second Language Acquisition, 25, 99-126. http://dx.doi.org/10.1017/S0272263103000044

Saerideh, A. (2011). Exploring the Teachers' Use of Spoken Corrective Feedback in Teaching Iranian EFL Learners at Different Levels of Proficiency. International Conference on Education and Educational Psychology (ICEEPSY 2011). Procedia-Social and Behavioral Sciences, 29(2011), 1859-1868. http://dx.doi.org/10.1016/j.sbspro.2011.11.435

Sara, K. (2010). Corrective Feedback for Learners of Varied Proficiency Levels: A Teacher's Choices. TESL Canada Journal, Vol. 27, No 2.

Schmidt, R., \& Frota, S. (1986). Developing basic conversational ability in a second language: A case study of an adult learner of Portuguese. In R. Day (Ed.), Talking to learn: Conversation in second language acquisition. (pp. 237-326). Rowley, MA: Newbury House.

Sheen, Y. H. (2004). Corrective feedback and learner uptake in communicative classrooms across instructional settings. Language Teaching Research, 8, 3, 263-300. http://dx.doi.org/10.1191/1362168804lr146oa 
Spada, N., \& Frohlich, M. (1995). COLT. Communicative Orientation of Language Teaching observation scheme: Coding conventions and applications. Sydney, Australia: National Centre for English Language Teaching and Research.

Suzuki, M. (2004). Corrective Feedback and Learner Uptake in Adult ESL Classrooms. Teachers College, Columbia University Working Papers in TESOL \& Applied Linguistics, Vol. 4, No. 2.

Swain, M. (1985). Communicative competence: Some roles of comprehensible input and comprehensible output in its development. In S. Gass \& C. Madden (Eds.), Input in second language acquisition. (pp. 235-253). Rowley, MA: Newbury House.

Williams, J. (2001). The effectiveness of spontaneous attention to form. System, 29, 325-40. http://dx.doi.org/10.1016/S0346-251X(01)00022-7

Yoshida, R. (2010). How Do Teachers and Learners Perceive Corrective Feedback in the Japanese Language Classroom? The Modern Language Journal, 94, 293-314. http://dx.doi.org/10.1111/j.1540-4781.2010.01022.x

\section{Copyright Disclaimer}

Copyright reserved by the author(s).

This article is an open-access article distributed under the terms and conditions of the Creative Commons Attribution license (http://creativecommons.org/licenses/by/3.0/). 